\title{
Predictors of early rebleeding after endoscopic therapy in patients with nonvariceal upper gastrointestinal bleeding secondary to high-risk lesions
}

\author{
Davide Maggio MD ${ }^{1}$, Alan N Barkun MD CM FRCPC FACP FAGA FACG MSc ${ }^{2,3}$, Myriam Martel BSc ${ }^{2}$,

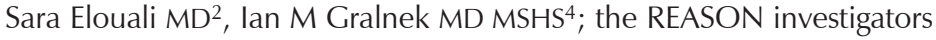

\begin{abstract}
D Maggio, AN Barkun, M Martel, S Elouali, IM Gralnek; the REASON investigators. Predictors of early rebleeding after endoscopic therapy in patients with nonvariceal upper gastrointestinal bleeding secondary to high-risk lesions. Can J Gastroenterol 2013;27(8):454-458.
\end{abstract}

BACKGROUND: In an era of increasingly shortened admissions, data regarding predictors of early rebleeding among patients with nonvariceal upper gastrointestinal bleeding (NVUGIB) exhibiting high-risk stigmata (HRS) having undergone endoscopic hemostasis are lacking. OBJECTIVES: To determine predictors of early rebleeding, defined as rebleeding before completion of recommended $72 \mathrm{~h}$ intravenous proton pump inhibitor infusion postendoscopic hemostasis.

METHODS: Data from a national registry of patients with upper gastrointestinal bleeding (the REASON registry) were accessed. Univariable and multivariable analyses were sequentially performed to identify significant independent predictors among a comprehensive list of clinical and laboratory characteristics.

RESULTS: Overall, 393 patients underwent endoscopic hemostasis for NVUGIB with HRS. Forty patients rebled $\leq 72 \mathrm{~h}$ thereafter $(32.5 \%$ female, mean $[ \pm$ SD] age $70.2 \pm 11.8$ years, $2.88 \pm 2.11$ comorbidities), while 21 rebled later $(38.1 \%$ female, mean $70.5 \pm 14.1$ years of age, $2.62 \pm 2.06$ comorbidities). Hematemesis or bright red blood per nasogastric tube aspirate was identified as the sole independent significant predictor of early rebleeding versus later among both NVUGIB and, more specifically, patients with peptic ulcer bleeding (OR 7.94 [95\% CI 1.80 to 35.01]; P<0.01, and OR 8.41 [95\% CI 1.54 to 46.10]; $\mathrm{P}=0.014$, respectively).

CONCLUSIONS: When attempting to determine the optimal duration of pharmacotherapy and timing of discharge for patients following endoscopic hemostasis for NVUGIB with HRS, it is noteworthy that individuals who present with hematemesis or bright red blood per nasogastric tube aspirate are at particularly high risk for rebleeding within the first $72 \mathrm{~h}$.

Key Words: Bleeding; Endoscopic therapy; Hemostasis; High-risk stigmata; Nonvariceal; Upper gastrointestinal tract
Les prédicteurs d'une reprise rapide des saignements après un traitement endoscopique chez des patients ayant des saignements gastro-intestinaux non variqueux en raison de lésions à haut risque

HISTORIQUE : À une époque d'hospitalisations toujours plus courtes, on possède peu de données sur les prédicteurs de reprise rapide des saignements chez les patients ayant des saignements non variqueux des voies digestives supérieures (SNVVDS) présentant des stigmates à haut risque (SHR) qui ont subi une hémostase endoscopique.

OBJECTIFS : Déterminer les prédicteurs de reprise rapide des saignements, définis comme la reprise des saignements avant la fin de l'infusion d'inhibiteurs de la pompe à protons recommandée pendant 72 heures après une hémostase postendoscopique.

MÉTHODOLOGIE : Les chercheurs ont consulté les données d'un registre national de patients ayant des saignements de voies digestives supérieures (le registre REASON). Ils ont effectué des analyses univariable et multivariables équentielles pour déterminer les prédicteurs indépendants importants dans une liste détaillée de caractéristiques cliniques et de laboratoire.

RÉSULTATS : Dans l'ensemble, 393 patients ont subi une hémostase endoscopique en raison de SNVVDS présentant des SHR. Quarante patients ont saigné de nouveau dans les 72 heures suivantes $(32,5 \%$ de femmes, âge moyen [ $[ \pm$ ÉT] de $70,2 \pm 11,8$ ans, $2,88 \pm 2,11$ comorbidités), tandis que 21 ont saigné plus tard $(38,1 \%$ de femmes, âge moyen de $70,5 \pm 14,1$ ans, 2,62 $\pm 2,06$ comorbidités). Les chercheurs ont établi qu'une hématémèse ou du sang rouge vif dans l'aspirat de la sonde nasogastrique étaient les seuls prédicteur indépendants d'importance d'une reprise rapide des saignements plutôt que de saignements plus tardifs chez des patients qui avaient des SNVVDS et, plus précisément, des saignements causés par un ulcère gastroduodénal (RRR 7,94 [95 \% IC 1,80 à 35,01]); $\mathrm{P}<0,01$, et RRR 8,41 [95 \% IC 1,54 à 46,10]; $\mathrm{P}=0,014$ ), respectivement).

CONCLUSIONS : Lorsqu'on tente de déterminer la durée optimale de la pharmacothérapie et le moment du congé des patients après une hémostase endoscopique secondaire à des SNVVDS accompagnés de SHR, il est bon de savoir que les personnes qui présentent une hématémèse ou du sang rouge vif dans l'aspirat de la sonde nasogastriques sont particulièrement vulnérables à la reprise des saignements dans les 72 heures.

appropriate level of care (ie, intensive care unit, monitored setting, ward, etc), while possibly guiding the route of administration and duration of subsequent acute pharmacotherapy.

Currently, it is recommended that patients with PUB secondary to high-risk lesions be hospitalized following endoscopic hemostasis for a minimum of $72 \mathrm{~h}$ while receiving a continuously infused proton pump inhibitor (PPI) drip as per existing guidelines (3). However, many centres appear to be discharging patients after only $48 \mathrm{~h}$ (4). The need for highdose intravenous (IV) PPI regimens postendoscopic therapy as opposed to lower dosing regimens has also been recently questioned (5-9). could help refine the triage of patients presenting with UGIB to their

${ }^{1}$ Department of Medicine; ${ }^{2}$ Division of Gastroenterology; ${ }^{3}$ Department of Epidemiology and Biostatistics and Occupational Health, McGill University

Health Centre, McGill University, Montreal, Quebec; ${ }^{4}$ Department of Gastroenterology and GI Outcomes Unit, Rambam Health Care Campus,

Bruce and Ruth Rappaport Faculty of Medicine, Technion-Israel Institute of Technology, Haifa, Israel

Correspondence: Dr Alan N Barkun, Room D7-346, Division of Gastroenterology, The McGill University Health Centre, Montreal, Quebec H3G 1A4.

Telephone 514-934-8309, fax 514-934-8531, e-mail alan.barkun@muhc.mcgill.ca

Received for publication April 17, 2013. Accepted May 12, 2013 
Based on this infomation, the current study aimed to determine predictors of rebleeding before the completion of the recommended $72 \mathrm{~h} \mathrm{IV} \mathrm{PPI} \mathrm{infusion} \mathrm{(versus} \mathrm{later)} \mathrm{following} \mathrm{endoscopic} \mathrm{hemostasis} \mathrm{in}$ patients with nonvariceal UGIB (NVUGIB) exhibiting high-risk stigmata (HRS).

\section{METHODS}

\section{The REASON registry}

The REgistry of patients undergoing endoscopic and/or Acid Suppression therapy and Outcomes analysis for upper gastrointestinal bleediNg (REASON) registry, a national registry of patients presenting with suspected UGIB, was used in an effort to determine whether any predictors of early rebleeding (defined as within $72 \mathrm{~h}$ of presentation), among patients with NVUGIB and HRS and, more specifically, patients with PUB and HRS, could be identified. The REASON registry was constructed as a retrospective medical chart review conducted in 21 Canadian hospitals (both tertiary and community institutions) in 2004 to 2005 (10). Briefly, sites reviewed the charts of all hospitalized patients $\geq 18$ years of age with a primary or secondary coded discharge diagnosis of UGIB. Patients initially assessed at another institution for the present episode of bleeding and subsequently transferred to the participating site were excluded, as were (for the purposes of the present analysis) all patients bleeding from variceal sources. A specialized web-based electronic data capture system was developed for this registry; study nurses and investigators received standardized training on the protocol and the specific data variables to be captured.

The entered data were reviewed centrally for internal logic of patient flow and biological plausibility. Data validation checks according to a predefined data validation scheme were conducted similar to those performed in previous registries by the current group of investigators (11). To further validate the abstracted information, $10 \%$ of all records were also audited by a second, independent study nurse.

Recorded information included demographics, historical data, physical examination findings and the yield of nasogastric (NG) aspirate, if performed, in addition to laboratory, management and outcomes data.

Several outcomes were collected using a priori standardized definitions: rebleeding was defined as overt hematemesis; passage of fresh blood from the rectum; a fall in hemoglobin concentration of $>2 \mathrm{~g} / \mathrm{L}$ within any $24 \mathrm{~h}$ period after the first $24 \mathrm{~h}$ following endoscopy hemostasis; shock (defined as a systolic blood pressure of $\leq 90 \mathrm{mmHg}$ or a heart rate $\geq 110$ beats/min) in the presence of continuing melena; or the presence of fresh blood in the stomach or duodenum, or both, at repeat endoscopy when further bleeding was suspected (11). Continued bleeding was defined as spurting or oozing arising from an artery on the initial endoscopic examination that did not respond to endoscopic therapy, or the persistence following initial endoscopy of: the presence of a bloody aspirate from NG tube (reinserted because of clinical suspicion); shock (defined as a systolic blood pressure $\leq 90 \mathrm{mmHg}$ or a heart rate rate $\geq 110$ beats/min); and/or the need for substantial replacement of blood and fluid volume (transfusion of $\geq 3$ units of blood within $4 \mathrm{~h}$ ) following endoscopic therapy (11). An a priori decision was made to group rebleeding and continued bleeding together for the purpose of all analyses as performed previously (11).

Information regarding rebleeding and its timing within 30 days of the patient's initial hospitalization was collected in addition to the timing of endoscopic hemostasis. A patient experiencing a subsequent bleed $>30$ days after the initial bleeding event was considered to have experienced a new bleeding episode.

\section{Data analysis}

Descriptive data were generated for the rebleeding rates and patient characteristics discussed above. All categorical data were expressed as proportions with $95 \%$ CIs determined using the normal approximation of the binomial distribution. Continuous data were expressed as mean \pm SD unless otherwise indicated.
Considering the natural history of the evolution of bleeding ulcers with HRS and its implications with regard to the duration of PPI infusion, as well as existing guidelines on acute pharmacological management of patients with NVUGIB, it was decided a priori to dichotomize the population according to early $(\leq 72 \mathrm{~h})$ or late rebleed $(>72 \mathrm{~h}$ ) for the initial univariable analysis (3).

The possible clinical variables included in the multivariable analysis aimed at identifying predictors of rebleeding early within the first $72 \mathrm{~h}$ after endosocopic hemostasis were chosen based on possible predictors identified in the literature and guided by the univariable analysis. Multivariable analysis was performed using logistic regression modelling. The optimal model yielded the highest $\mathrm{C}$ coefficient score while being the most parsimonious. All analyses were performed using SAS software version 9.2 (SAS Institute, USA).

\section{Patient population}

\section{RESULTS}

The REASON database included a total of 1805 NVUGIB patients, of whom 393 demonstrated HRS on endoscopy and underwent endoscopic hemostasis and, of these, 61 rebled within the first 30 days. Although not significant, the proportion of female patients was greater in the group that rebled after $72 \mathrm{~h}(38.1 \%)$ compared with the group that bled within the first $72 \mathrm{~h}(32.5 \%)$. The mean ages and numbers of comorbid conditions were similar (rebleeding $\leq 72$ h: $70.2 \pm 11.8$ years and $2.88 \pm 2.11$ comorbidities versus rebleeding $>72 \mathrm{~h}: 70.5 \pm 14.1$ years and $2.62 \pm 2.06$ comorbidities) (Table 1 ). The rebleeding rate among patients exhibiting HRS overall was $15.5 \%$ (61 of 393). In comparison, the rebleeding rate for low-risk stigmata (Forrest IIc = flat pigmented spot and Forrest III = clean base ulcer) was 7.1\% (18 of 255); $99.4 \%$ of patients received a PPI during their hospital stay.

\section{Time to rebleed}

Among 61 patients with HRS who rebled, the majority ( $\mathrm{n}=40$ [65.6\%]) did so within the first $72 \mathrm{~h}$. Of these, the mean time to rebleed was $1.38 \pm 0.63$ days (Figure 1). Figure 2 illustrates the breakdown of rebleeders among the patients who experienced this complicated course within the first $72 \mathrm{~h}$

\section{Predictors of early rebleeding}

Table 1 reports the results of the univariable analysis for possible predictors of early rebleeding in all NVUGIB patients with HRS: hematemesis or bright red blood per NG tube aspirate on initial presentation was the sole significant predictor of early rebleeding $(\mathrm{P}=0.03)$.

The best, most parsimonious logistic regression model is shown in Table $2(\mathrm{C}$ statistic $=0.764)$. The sole significant independent predictor of early rebleeding in all NVUGIB patients with HRS was hematemesis or bright red blood per NG tube aspirate on initial presentation (OR 7.94 [95\% CI 1.80 to 35.01]; $\mathrm{P}=0.0062$ ) (Table 2). An American Society of Anesthesiologists (ASA) score of 1 to 3 was associated with a trend toward earlier rebleeding in the first three days, as was an elevated presenting international normalized ratio (INR).

Multivariable analysis was similarly performed for the subgroup of patients with PUB and HRS. Within this group, the sole significant independent predictor of early rebleeding was also hematemesis or bright red blood per NG tube aspirate on initial presentation (OR 8.41 [95\% CI 1.54 to 46.1]; $\mathrm{P}=0.0149$ ) (Table 3).

\section{DISCUSSION}

NVUGIB accounts for a significant number of hospitalizations in North America (11), mainly due to PUB (12). Rebleeding in NVUGIB occurs in approximately $8 \%$ to $25 \%$ of patients, despite endoscopic therapy (13). Predictors of rebleeding have been previously identified in the literature $(2,14-23)$. These include bedside (hemodynamic instability, comorbid illness and hemoglobin level at presentation) and endoscopic predictors (active bleeding at endoscopy, ulcer size and ulcer location). 
TABLE 1

Study population characteristics at initial presentation including historical, physical examination and laboratory value variables (univariable analysis)

\begin{tabular}{|c|c|c|c|}
\hline \multirow[b]{2}{*}{ Characteristic } & \multicolumn{2}{|c|}{ Rebleeding postendoscopic hemostasis } & \multirow[b]{2}{*}{$\mathbf{P}$} \\
\hline & $\leq 3$ days $(n=40)$ & $>3$ days $(n=21)$ & \\
\hline Female sex & $32.5(7.3-47.7)$ & $38.1(15.4-60.8)$ & 0.6621 \\
\hline Age, years, mean \pm SD & $70.2 \pm 11.8$ & $70.5 \pm 14.1$ & 0.9097 \\
\hline Number of comorbid conditions, mean \pm SD & $2.88 \pm 2.11$ & $2.62 \pm 2.06$ & 0.8005 \\
\hline Baseline ASA score* 1 to 3 & $85.0(73.4-96.6)$ & $71.4(50.4-92.5)$ & 0.2052 \\
\hline Hemodynamic instability & $50.0(33.8-66.2)$ & $28.6(7.5-49.6)$ & 0.1078 \\
\hline Inpatient & $25.0(11.0-39.0)$ & $28.6(7.5-49.6)$ & 0.7632 \\
\hline Rectal bleeding & $7.5(0.0-16.0)$ & $14.3(0.0-30.6)$ & 0.3978 \\
\hline $\begin{array}{l}\text { Hematemesis or bright red blood per nasogastric tube } \\
\text { aspirate on initial presentation }\end{array}$ & $47.5(31.3-63.7)$ & $19.1(0.7-37.4)$ & 0.0294 \\
\hline Epinephrine injection alone & $40.0(24.1-55.9)$ & $23.8(3.9-43.7)$ & 0.2060 \\
\hline Hemoglobin on presentation, $g / L$, mean \pm SD & $90.4 \pm 25.7$ & $89.9 \pm 34.4$ & 0.5661 \\
\hline Presenting international normalized ratio $^{\dagger}$, mean \pm SD & $1.52 \pm 0.68$ & $1.35 \pm 0.58$ & 0.3514 \\
\hline
\end{tabular}

Data presented as \% (95\% Cl) unless otherwise indicated. All patients received intravenous proton pump inhibitors during the hospital admission, pre/post endoscopy. *American Society of Anesthesiologists (ASA) score refers to classification of a patient's severity and acuity of disease index; ${ }^{\dagger}$ Rebleed $\leq 3$ days ( $n=36$ ), rebleed $>3$ days $(n=19)$

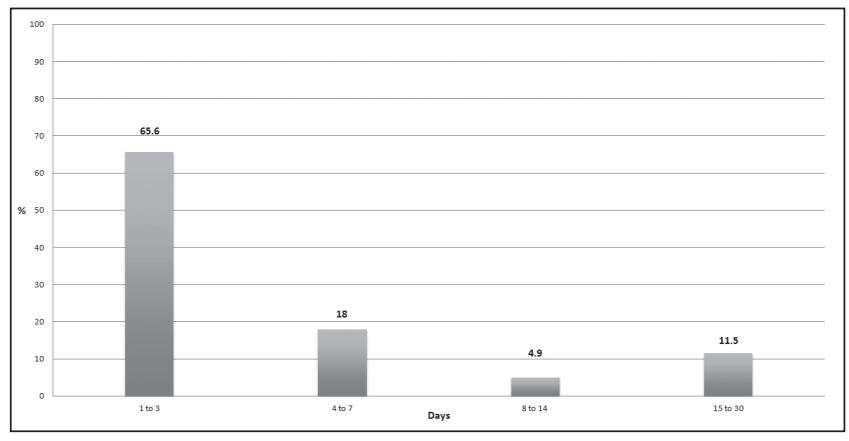

Figure 1) Distribution of patients with rebleeding from nonvariceal upper gastrointestinal bleeding with high-risk stigmata within the first 30 days

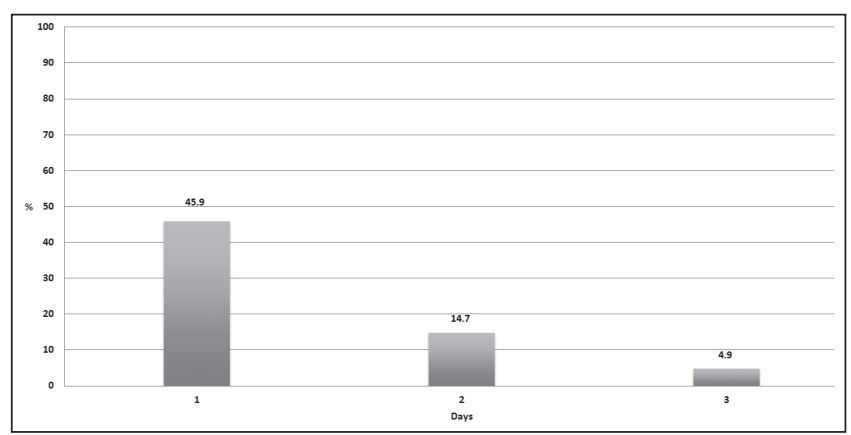

Figure 2) Distribution of patients with rebleeding from nonvariceal upper gastrointestinal bleeding with high-risk stigmata within the first $72 \mathrm{~h}$

A study by Lau et al (24) demonstrated the natural evolution of stigmata of recent hemorrhage by performing serial endoscopy and found that the majority of these lesions evolved into clean-based ulcers within three days following endoscopic hemostasis. Based on clinical observations, consensus groups have stated that the majority of rebleeding occurs within the first three days after endoscopic therapy (3). This is why high-dose IV PPI infusion is currently recommended for a full $72 \mathrm{~h}$ after hemostasis $(3,25)$, with confirmation of efficacy in a Cochrane meta-analysis update (26). However, some centres have begun selectively discharging such patients before completing the full $72 \mathrm{~h}$ of IV PPI therapy (4), with wide variations in the implementation of practice guidelines (8). Because of these potentially important disparities in practice, we sought to better define predictors of early rebleeding and, more specifically, within the first $72 \mathrm{~h}$ of endoscopic therapy, using nationally collected registry data.
TABLE 2

Independent predictors of early rebleeding in multivariable analysis in all nonvariceal upper gastrointestinal bleeding

\begin{tabular}{lcc}
\hline Effect & OR (95\% Cl) & $\mathbf{P}$ \\
\hline $\begin{array}{l}\text { Hematemesis or bright red blood per } \\
\text { nasogastric tube aspirate on initial }\end{array}$ & $7.94(1.80-35.01)$ & 0.0062 \\
$\quad$ & & \\
presentation & $4.33(0.74-24.91)$ & 0.1004 \\
Baseline ASA class 1 to 3* & $2.74(0.81-9.28)$ & 0.1048 \\
\hline Presenting INR
\end{tabular}

${ }^{*}$ American Society of Anesthesiologists (ASA) score refers to the classification of a patient's severity and acuity of disease index; ' INR International normalized ratio, rebleed $\leq 3$ days $(n=36)$, rebleed $>3$ days $(n=19)$

TABLE 3

Independent predictors of early rebleeding in multivariable analysis in peptic ulcer disease bleeding only

\begin{tabular}{lcc}
\hline Effect & OR $(95 \%$ Cl) & P \\
\hline $\begin{array}{l}\text { Hematemesis or bright red blood per } \\
\text { nasogastric tube aspirate on initial } \\
\text { presentation }\end{array}$ & $8.41(1.54-46.10)$ & 0.0141 \\
Presenting international normalized ratio & $4.81(0.75-30.84)$ & 0.1048 \\
\hline
\end{tabular}

In our analysis of the REASON database, hematemesis or bright red blood per NG aspirate at initial presentation was the sole significant independent predictor of rebleeding within the first $72 \mathrm{~h}$ after endoscopic hemostasis versus later. These characteristics may be a surrogate marker for the presence of a larger-calibre bleeding vessel, which may respond poorly to current therapeutic modalities or unfavourable physiological circumstances and, thereby, identify a patient at higher risk for earlier rebleeding.

These findings would appear to support the use of NG aspiration without lavage in initial prognostication (16) and risk stratification of patients with NVUGIB, especially in light of data suggesting extreme variations in its use (8), with progressively fewer patients undergoing NG tube insertion for sole sampling (27). Furthermore, it has also been suggested that patients with a bloody NG aspirate may represent a subgroup of patients in whom the administration of pre-endoscopic PPI is cost effective $(28,29)$. In contrast, the performance of selectively complementing aspiration with NG lavage is gradually being replaced by the administration of prokinetics (30).

Current recommendations support the use of routine second-look endoscopy in certain high-risk patients $(3,31)$. Whether patients presenting with hematemesis or bright red blood per NG tube represent 
such a population in which a second-look endoscopy may be beneficial because they are at particularly high risk of rebleeding within the first three days requires further investigation.

In the best model we present, two additional prognosticators displayed strong trends toward rebleeding early within the first $72 \mathrm{~h}$, albeit without achieving statistically significant discrimination, and warrant further discussion. It is well recognized that a higher ASA score is associated with increased rebleeding over the following 30 days (32). Our analysis also suggests that patients with an ASA score of 4 or 5 may be at increased risk for delayed rebleeding following endoscopic hemostasis; however, this finding did not attain statistical significance. Interestingly, a study by Cheng et al (33), which included a much greater proportion of patients with ASA scores of 4 or 5 (37.1\%), also demonstrated a more delayed mean time to rebleeding (rebleeding within the first three days ranged from $11.3 \%$ to $15.4 \%$ and increased to $40.4 \%$ to $43.4 \%$ by day 28) (33). One explanation for this finding may be that sicker patients experience impaired wound healing, putting them at increased risk for delayed rebleeding. Cheng et al also found that patients with a low serum albumin level (eg, <30 g/L), had a cumulative rebleeding rate that increased significantly during days 4 to 14 . The authors, thus, also suggested that the bioavailability of oral omeprazole may be affected by low serum albumin levels in sicker patients. Both mechanistic conclusions remain speculative and require further study. One also cannot rule out alternative methodological explanations for the association of delayed bleeding and increased ASA score. Bias may have occurred; for example, it may be that sicker patients are less likely to be rescoped early, with a decreased rebleeding detection rate in the presence of otherwise poorly interpretable clinical criteria. Finally, a type II error may also be present.

Regarding the trend noted with the presenting INR ratio value, although an elevated INR has been recently linked to increased mortality, its relationship with rebleeding remains controversial $(3,34)$. Nonetheless, plausible physiological reasons linking an elevated INR to a possible rebleeding event within the first $72 \mathrm{~h}$ after endoscopic hemostasis exist and could explain the observed trend in our final model. Confounding factors may have included the cause of the INR elevation and varying degrees of aggressiveness in correcting, although, here too, a type II error cannot be ruled out.

The REASON database did not allow us to study some predictors of rebleeding after endoscopic treatment that have been identified in the literature. These include ulcer size and location (35); similarly, we had limited information regarding transfusional requirements that have recently also been proposed as possible predictors of rebleeding (36-38).

The observational nature of our data also limits our results and should be regarded as hypothesis-generating to better guide subsequent research in the area.

\section{CONCLUSION}

Hematemesis or bright red blood per NG aspirate was the sole independent significant predictor of rebleeding within the first $72 \mathrm{~h}$ versus later following endoscopic hemostasis among patients with NVUGIB endoscopically treated for HRS. When attempting to determine the optimal timing of discharge for such patients, it is important to realize that individuals who present with hematemesis or bright red blood per NG tube aspirate are at particularly high risk for earlier rebleeding within those critical first $72 \mathrm{~h}$. These patients should be kept in hospital accordingly, and may further justify the current recommendations of administering an IV PPI for the full $72 \mathrm{~h}$. Possible relationships between the timing of early rebleeding and both presenting ASA score and INR require further characterization.

AUTHOR CONTRIBUTIONS: Guarantor of the article: Dr Alan Barkun. Specific author contributions: Conception and design; Davide
Maggio, Alan N Barkun, Ian M Gralnek. Analysis and interpretation of the data; Davide Maggio, Alan N Barkun, Myriam Martel, Sara Elouali, Ian M Gralnek. Drafting of the manuscript; Davide Maggio, Alan N Barkun. Critical revision of the manuscript for important intellectual content: Davide Maggio, Alan N Barkun, Ian M Gralnek. Final approval of the article: Davide Maggio, Alan N Barkun, Myriam Martel, Sara Elouali, Ian M Gralnek.

FUNDING: No financial support was received.

DISCLOSURES: Alan Barkun is a consultant for AstraZeneca, Takeda Canada, Boston Scientific Inc and Olympus Canada. No conflicts of interest exist for Davide Maggio, Myriam Martel and Ian M Gralnek.

\section{REFERENCES}

1. Gralnek IM, Barkun AN, Bardou M. Management of acute bleeding from a peptic ulcer. N Engl J Med 2008;359:928-37.

2. Elmunzer BJ, Young SD, Inadomi JM, Schoenfeld P, Laine L. Systematic review of the predictors of recurrent hemorrhage after endoscopic hemostatic therapy for bleeding peptic ulcers. Am J Gastroenterol 2008;103:2625-32.

3. Barkun AN, Bardou M, Kuipers EJ, et al. International consensus recommendations on the management of patients with nonvariceal upper gastrointestinal bleeding. Ann Intern Med 2010;152:101-13.

4. Barkun AN, Bhat M, Armstrong D et al. Effectiveness of disseminating consensus management recommendations for ulcer bleeding: A cluster randomized trial. CMAJ 2013;185:E156-66.

5. Andriulli A, Annese V, Caruso N, et al. Proton-pump inhibitors and outcome of endoscopic hemostasis in bleeding peptic ulcers: A series of meta-analyses. Am J Gastroenterol 2005;100:207-19.

6. Andriulli A, Loperfido S, Focareta R, et al. High-versus low-dose proton pump inhibitors after endoscopic hemostasis in patients with peptic ulcer bleeding: A multicentre, randomized study. Am J Gastroenterol 2008;103:3011-8.

7. Barkun AN, Thomson A, Marshall J, Bardou M. Response to "Potentially flawed interpretation of data by Andriulli et al." Am J Gastroenterol 2005;100:2133; author reply 4.

8. Esrailian E, Gralnek IM, Jensen D, et al. Evaluating the process of care in nonvariceal upper gastrointestinal haemorrhage: A survey of expert vs. non-expert gastroenterologists. Aliment Pharmacol Ther 2008;28:1199-208

9. Wang $\mathrm{CH}$, Ma MH, Chou HC, et al. High-dose vs non-high-dose proton pump inhibitors after endoscopic treatment in patients with bleeding peptic ulcer: A systematic review and meta-analysis of randomized controlled trials. Arch Intern Med 2010;170:751-8.

10. Barkun AN, Gasco A, Jewell D. Management of Nonvariceal Upper GI Bleeding (NVUGIB) After Guideline Publication: The Reason Study. Can J Gastroenterol 2006;20(Suppl A):80A \#87. (Abst)

11. Barkun A, Sabbah S, Enns R, et al. The Canadian Registry on Nonvariceal Upper Gastrointestinal Bleeding and Endoscopy (RUGBE): Endoscopic hemostasis and proton pump inhibition are associated with improved outcomes in a real-life setting. Am J Gastroenterol 2004;99:1238-46.

12. van Leerdam ME, Vreeburg EM, Rauws EA, et al. Acute upper GI bleeding: Did anything change? Time trend analysis of incidence and outcome of acute upper GI bleeding between 1993/1994 and 2000. Am J Gastroenterol 2003;98:1494-9.

13. van Leerdam ME. Epidemiology of acute upper gastrointestinal bleeding. Best Pract Res Clin Gastroenterol 2008;22:209-24.

14. Brullet E, Campo R, Calvet X, Coroleu D, Rivero E, Simo Deu J. Factors related to the failure of endoscopic injection therapy for bleeding gastric ulcer. Gut 1996;39:155-8.

15. Villanueva C, Balanzo J, Espinos JC, et al. Prediction of therapeutic failure in patients with bleeding peptic ulcer treated with endoscopic injection. Dig Dis Sci 1993;38:2062-70.

16. Wong SK, Yu LM, Lau JY, et al. Prediction of therapeutic failure after adrenaline injection plus heater probe treatment in patients with bleeding peptic ulcer. Gut 2002;50:322-5.

17. Chung IK, Kim EJ, Lee MS, et al. Endoscopic factors predisposing to rebleeding following endoscopic hemostasis in bleeding peptic ulcers. Endoscopy 2001;33:969-75.

18. Thomopoulos KC, Mitropoulos JA, Katsakoulis EC, et al. Factors associated with failure of endoscopic injection haemostasis in bleeding peptic ulcers. Scand J Gastroenterol 2001;36:664-8. 
19. Park KG, Steele RJ, Mollison J, Crofts TJ. Prediction of recurrent bleeding after endoscopic haemostasis in non-variceal upper gastrointestinal haemorrhage. Br J Surg 1994;81:1465-8.

20. Huang YS, Lin HJ, Fang YR, Wang K, Chang FY, Lee SD. Development and validation of a scoring system predicting failure of endoscopic epinephrine injection therapy in Taiwanese patients with bleeding peptic ulcers. Zhonghua Yi Xue Za Zhi (Taipei). 2002;65:144-50.

21. Lin HJ, Tseng GY, Lo WC, et al. Predictive factors for rebleeding in patients with peptic ulcer bleeding after multipolar electrocoagulation: A retrospective analysis. J Clin Gastroenterol 1998;26:113-6.

22. Shahid M, Ashfaq A, Wasim J. Predictors of rebleed in actively bleeding duodenal ulcer after endoscopic intervention in a developing Asian Country. Am J Gastroenterol 2007;102(Suppl 2):S520.

23. Toki M, Yamaguchi, Y, Nakamura, K, et al. Predictive risk factors for rebleeding and thirty day mortality after endoscopic hemostasis in elderly bleeding peptic ulcer patients. Gastrointest Endosc 2008;67:AB240. (Abst)

24. Lau JY, Chung SC, Leung JW, Lo KK, Yung MY, Li AK. The evolution of stigmata of hemorrhage in bleeding peptic ulcers: A sequential endoscopic study. Endoscopy 1998;30:513-8.

25. Barkun AN, Cockeram AW, Plourde V, Fedorak RN. Acid suppression in non-variceal acute upper gastrointestinal bleeding. Aliment Pharmacol Ther 1999;13:1565-84.

26. Leontiadis GI, Sharma VK, Howden CW. Proton pump inhibitor therapy for peptic ulcer bleeding: Cochrane collaboration meta-analysis of randomized controlled trials. Mayo Clin Proc 2007;82:286-96.

27. Bensoussan K, Fallone CA, Barkun AN, Martel M. A sampling of Canadian practice in managing nonvariceal upper gastrointestinal bleeding before recent guideline publication: Is there room for improvement? Can J Gastroenterol 2005;19:487-95.

28. Barkun AN. Should every patient with suspected upper GI bleeding receive a proton pump inhibitor while awaiting endoscopy? Gastrointest Endosc 2008;67:1064-6.
29. Al-Sabah S, Barkun AN, Herba K, et al. Cost-effectiveness of proton-pump inhibition before endoscopy in upper gastrointestinal bleeding. Clin Gastroenterol Hepatol 2008;6:418-25.

30. Barkun AN, Bardou M, Martel M, Gralnek IM, Sung JJ. Prokinetics in acute upper GI bleeding: A meta-analysis. Gastrointest Endosc 2010;72:1138-45.

31. El Ouali S, Barkun AN, Wyse J, et al. Is routine second-look endoscopy effective after endoscopic hemostasis in acute peptic ulcer bleeding? A meta-analysis Gastrointest Endosc 2012;76:283-92.

32. Barkun A, Bardou M, Marshall JK. Consensus recommendations for managing patients with nonvariceal upper gastrointestinal bleeding. Ann Intern Med 2003;139:843-57.

33. Cheng HC, Kao AW, Chuang CH, Sheu BS. The efficacy of highand low-dose intravenous omeprazole in preventing rebleeding for patients with bleeding peptic ulcers and comorbid illnesses. Dig Dis Sci 2005;50:1194-201.

34. Shingina A, Barkun AN, Razzaghi A, Martel M, Bardou M, Gralnek I. Systematic review: The presenting international normalised ratio (INR) as a predictor of outcome in patients with upper nonvariceal gastrointestinal bleeding. Aliment Pharmacol Ther 2011;33:1010-8.

35. Garcia-Iglesias P, Villoria A, Suarez D, et al. Meta-analysis: Predictors of rebleeding after endoscopic treatment for bleeding peptic ulcer. Aliment Pharmacol Ther 2011;34:888-900.

36. Restellini S, Kherad O, Jairath V, Martel M, Barkun AN. Red blood cell transfusion is associated with increased rebleeding in patients with nonvariceal upper gastrointestinal bleeding. Aliment Pharmacol Ther 2013;37:316-22.

37. Jairath V, Hearnshaw S, Brunskill SJ, et al. Red cell transfusion for the management of upper gastrointestinal haemorrhage. Cochrane Database Syst Rev 2010(9):CD006613.

38. Villanueva C, Colomo A, Bosch A, et al. Transfusion strategies for acute upper gastrointestinal bleeding. N Engl J Med 2013;368:11-21. 


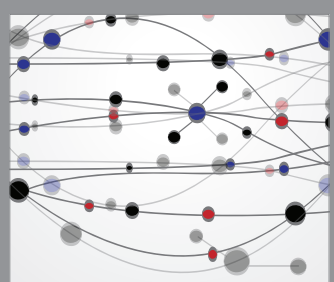

The Scientific World Journal
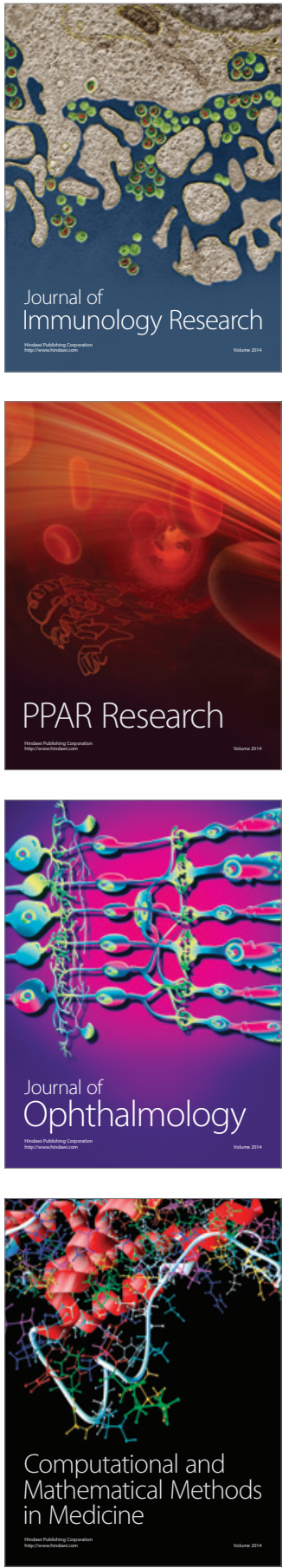

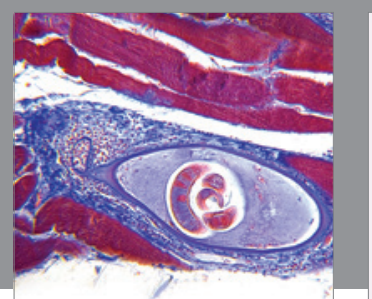

Gastroenterology Research and Practice

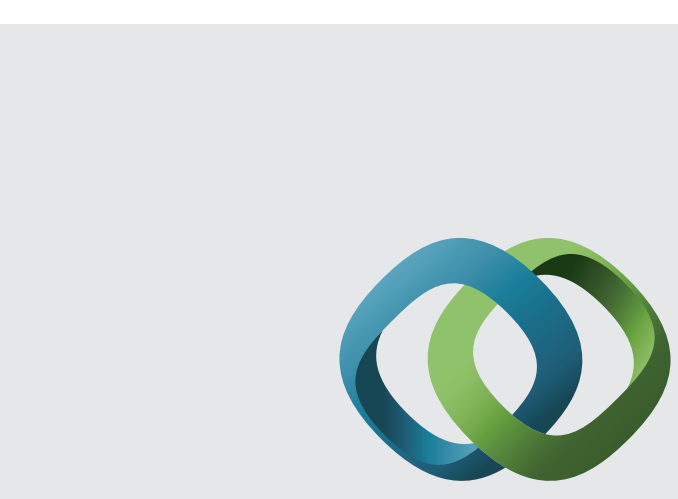

\section{Hindawi}

Submit your manuscripts at

http://www.hindawi.com
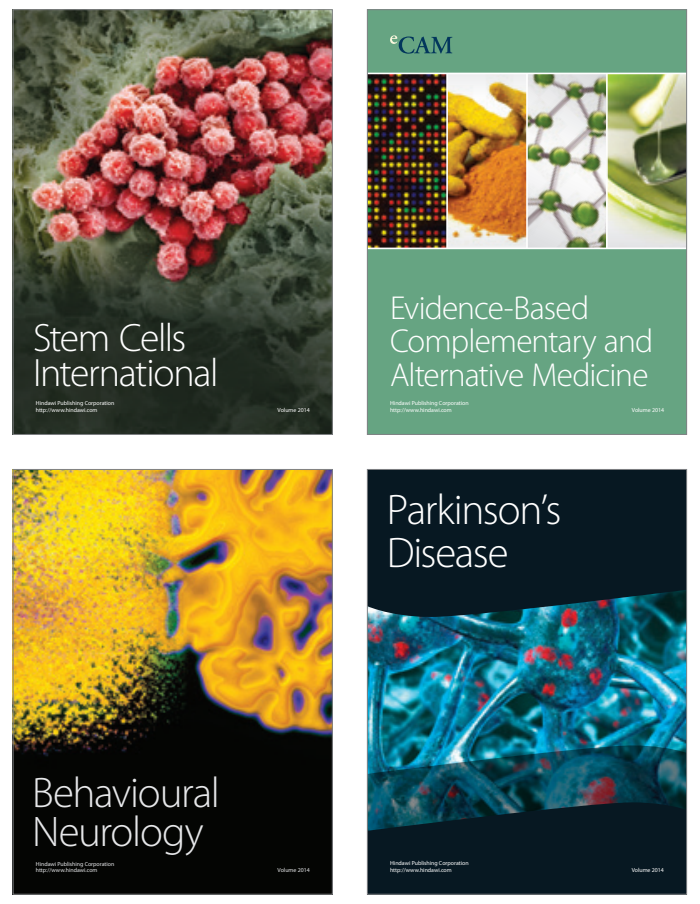
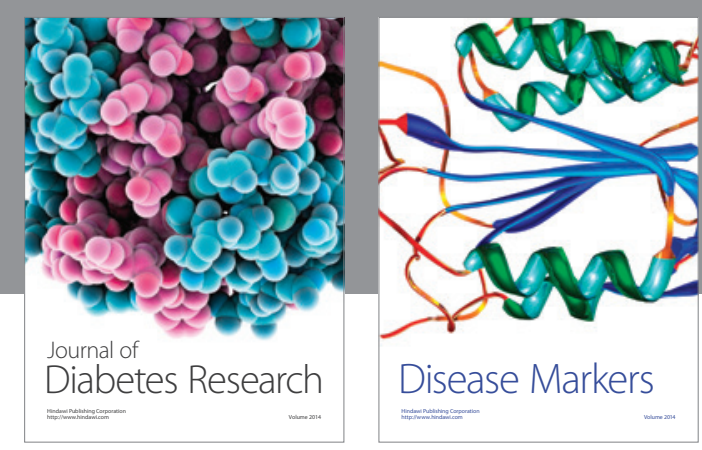

Disease Markers
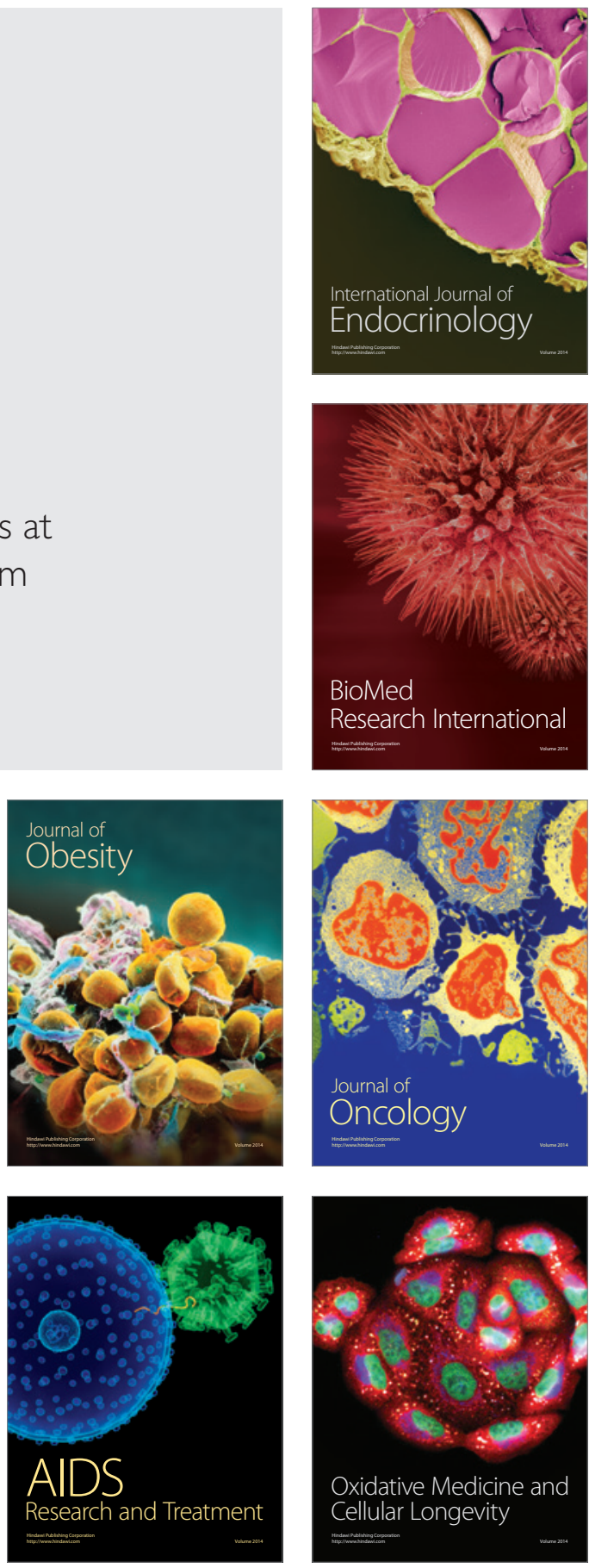